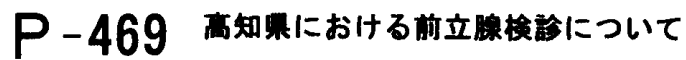

\author{
高知医大 ${ }^{1)}$ 、窪川保健所 ${ }^{2}$ 、土佐市民 ${ }^{3)}$ 、 \\ 十和村保健対策課 4$)$ \\ 片岡真一1)、執印太郎 ${ }^{11)}$ 、小松洋文 ${ }^{2)}$ 、谷村正信 ${ }^{31}$ 、 \\ 田浐豊 ${ }^{41}$
}

【目的】前立腺癌は近年湋増しており、本症の早期発見を目 的に、県西部に位圈する十和村において管轄の窪川保健所の 協力の下に、1996 年から前立腺検診を開始したので報告する。 【対象と方法】50 歳以上で本検診を希望するものを対象とし た。一次検診としてPSA（Delfia）の測定と、I P S K 準じた問診を行なった。この際のP S Aが $4.0 \mathrm{ng} / \mathrm{ml}$ 以上のも のを要二次検診者とし、再度の採血と直腸診、経直腸的超音 波検査等を行ない、必要に応じ精密検査を勧めた。

【結果と考察】1996 年は、対象者 725 名中受診者は 233 名で あり、60歳台が最も多く、次いで 70 歳台が多かった。228名 中 17 名のP S Aが 4. 0ng/ml 以上であったが、1名は 87 歳と 高齢のため 16 名を二次検診対象とし、1名を除く 15 名が受 診した。P S Aの再測定值は $4.0 \mathrm{ng} / \mathrm{ml}$ 未満が 4 例、 4.0 から $9.9 \mathrm{ng} / \mathrm{ml}$ が 7 例、 $10.0 \mathrm{ng} / \mathrm{ml}$ が 4 例であった。直腸診では 3 例に、超音波検查では 6 例に癌の疑いを認めた。再検分のP $\mathrm{S} \mathrm{A} \mathrm{でもこの} 6$ 例は $4.0 \mathrm{ng} / \mathrm{m} 1$ 以上であったため、精密検查の 対象者はこれら6名とした。この内訳は 2 名が癌、2 名がB P H、1名が異常なし、1名が未受診である。以上より要二次検 診者 16 名 (6.9\%) 、要精密検診者 6 名 $(2.6 \%)$ であった。 最終的に穜と診断されたものは一次検診者の $0.9 \%$ あ゙あった。 尚、1997 年も実施しており、この結果についても報告する。

\section{$P-470$ 姫路地域における前立腺结の度学} 姫路赤十字病院 ${ }^{11}$ ，国立姬路病院"2)，姫路聖マリア病院 ${ }^{31}$ ， 新日鉄公畑病院 ${ }^{11}$

小川隆義"，岡泰彦")，東由紀子"，橋村孝幸"2，岩村浩志 ${ }^{2}$ ，

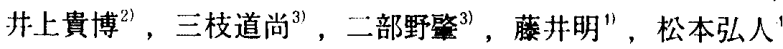

姫路地域における前立腺癌の疫学につき検討した。1994年 から1996年の3年間に組織学的に前立腺癌と診断されたのは， それぞれ $61 ， 50 ， 55$ 人の計 166 人で，年齡的には70歳代が $47.3 \%$ と最も多かった。粗罪患率は人口10万人/年あたり 11.6 〜15.4であり，市内とその周辺地域との間に差は見られなかっ た。主訴として排尿障害が $63.0 \%$ と多く認められたが，PSA高 做のため偶然発見された症例が11例に見られた。各年代とも StageDが最も多く全体として $45.7 \%$ 占めていた。年齢別検 吋では若年者ほどStageDの占める割合が大きかった。分化度 に㧍ける検討でも50歳代は他の年代に比べ中等度分化型が多 く，逆に高分化型の占める割合は高齢になる程高い傾向にあっ た。PSAはStageDでも $13.0 \%$ が正常範国内にあり，全体として は21.7\%がそれぞれ正常域, Gray zoneにあった。Gray zone の検討ではStageBが $48.5 \%$ と最も多かった。高分化型のもの はPSAが低く，低分化型のものは高い傾向が見られたが，中等 度分化型に比べ低分化型に正常範囲内のものが多かった。初 回治療としてホルモン療法単独が59.0\%と压倒的に多かった が，19.9\%に根治的手術療法が行なわれた。

\section{$P-471$}

虎の門病院におけるドック前立腺捦診の現況 虎の門病院泌尿器科 1)、同 健康医学センタ-2) 村田浩克 1),佐藤俊和 1),小田裕之 1),北原研 1),金村三樹郎 1),鉿 木正夫 1),横山正夫 1),吉承英世 2)

虎の門病院健康医学センターでは1日ドックのオプションとし て前立腺検診を 1993 年 6 月に閉始した。検診方法は受彰者に

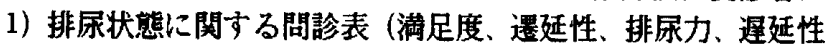
残烁感、夜問頻尿および尿失禁を各々三段階)、2）尿流量測定 (尿量、最大尿流率、平均尿流率、排尿時間)，3）血清 PAP(94 年 11 月 14 日まで)又は血清 PSA(94 年 11 月 15 日以降)測定、 4)経直腸的超音波検查(TRUS)を施行した。問診表、尿流量測定 TRUSの結果より総合判定としてA 正常、B 要経過稓察、C 要 精密検査 (泌尿器科受診必要) とし本人に通知した。1997 年 6 月までの受診者は 874 名であり平均年㱓は 54 歳 (25-84 歳) で、50 歳代が 362 名 (41\%) であった。今回の検討では年粭 と最大尿流率、平均尿流率及び TRUSより求めた前立腺重量と の間に明らかな相関を認めなかった。問診表より排尿状態を 各々スコア化しそのスコアと最大尿流率、平均尿流率に差があ るかどうかの検討では排烁力にのみ有意差 $(\mathrm{p}<0.0001)$ が た。総合判定ではA 306 名、B 446 名、C 120 名、判定不能 2 名であり実際に泌尿器科を受診した例はA 26 名 (8.5\%) B128 名 $(28.7 \%)$ C75 名 $(62.5 \%)$ であった。泌尿器科受診後、前 立腺肥大症の診断にて 4 例に TUR-P が施行され前立腺癌の疑 いにて 24 例に針生模が施行された。24 例中 3 例に前立腺雗

(Stage B:2, C:1)が発見された。今後もこの検診により治療を 要する前立腺肥大症、前立腺癌の早期発見が期待される。

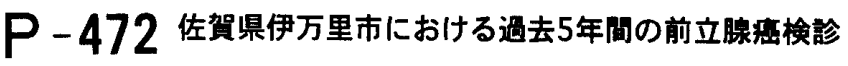

佐賀医科大学

倉冨一成 · 徳田雄治 - 高木紀人 . 平田祐司 - 中村晃二 佐藤伸二・吉永英俊 $\cdot$ 藤山千里・市木康久 $\cdot$ 真崎善二郎

【目的】前立腺癌集団検診での血清PSA測定のみによる一次 検診の有用性を過去 5 年間の結果をもとに検討する。【対象と 方法】前立腺癌検診は佐賀県伊万里市で平成4年度より開始し、 以後毎年実施している。対象は同市在住の住民総合健康診断 の受診者で根治的治療が期待できかつ発見率も低くないと考 えられる60〜69才の男性とした。方法は一次検診として血清 PSA測定(DELFIA)のみを行った。血清PSA值 $3.1 \mathrm{ng} / \mathrm{ml}$ 以上の者 を二次検診の対象とし、問診、直腸診(DRE)および経直腸超音 波検査(TRUS)を行った。三次検診は1)血清PSA值 $10.0 \mathrm{ng} / \mathrm{ml}$ 以 上。2)血清PSA值 $4.0 \mathrm{ng} / \mathrm{ml}$ 以上、 $10.0 \mathrm{ng} / \mathrm{ml}$ 末満でPSAD0.20以 上。3)上記1),2)以外でDREまたはTRUSで前立腺癌が疑われる 者を対象とし超音波下針生検を行った。【結果】過去5年間で 総一次検診受診者 3124 名(重複受診者含む)で、二次検診は対象 者260名中受診者209名に行った。三次検診は対象者102名中受 診者83名に行ったが前立腺癌を18名に発見し、棇一次検診受 診者に対する発見率は $0.58 \%$ 、三次検診受診者に対する発見率 は21.7\%であった。発見された前立腺癌の臨床病期は、stage B 15名、stage C 2名、stage D 1名であった。【考察】PSAのみの 一次検診を用いたこの方法は前立腺癌集団検診においてTRUS やDREに必要な泌尿器科医の労力を節減しつつもほほ满足で きる癌発見率を得ることができた。また検診を三段階とする ことにより生検受診者に対する癌確定者の割合を高くするこ とが可能となり、検診受診者にとっての不必要な生検を行う ことによる精神的、肉体的負担を軽減できたものと思われる。 